OPEN ACCESS

Edited by:

Craig E. Colten,

Louisiana State University,

United States

Reviewed by:

Adelle Thomas,

University of The Bahamas, Bahamas

Athanasios Votsis,

University of Twente, Netherlands

*Correspondence:

Michelle Mycoo

michelle.mycoo@sta.uwi.edu

${ }^{\dagger}$ These authors share first authorship

Specialty section:

This article was submitted to

Land Use Dynamics,

a section of the journal

Frontiers in Environmental Science

Received: 30 December 2020 Accepted: 26 April 2021

Published: 31 May 2021

Citation:

Mycoo M, Robinson S-A, Nguyen C, Nisbet $C$ and Tonkel $R$ (2021) Human

Adaptation to Coastal Hazards in

Greater Bridgetown, Barbados.

Front. Environ. Sci. 9:647788.

doi: $10.3389 /$ fenvs.2021.647788

\section{Human Adaptation to Coastal Hazards in Greater Bridgetown, Barbados}

\author{
Michelle Mycoo ${ }^{1 * t}$, Stacy-Ann Robinson ${ }^{2 \dagger}$, Cindy Nguyen ${ }^{2}$, Catherine Nisbet $^{2}$ and \\ Rock Tonkel III ${ }^{2}$ \\ ${ }^{1}$ Department of Geomatics Engineering and Land Management, The University of the West Indies, St. Augustine, Trinidad and \\ Tobago, ${ }^{2}$ Environmental Studies Program, Colby College, Waterville, ME, United States
}

As urban risks associated with a changing climate continue to intensify, it is increasingly important to broaden our understanding of climate vulnerabilities in coastal cities and human adaptation to climate-related hazards. Coastal cities in small island developing states in the Caribbean stand to be among the most climate-impacted. This paper explores vulnerability to coastal hazards (sea-level rise, storm surges and flooding) in Barbados' capital city and its urban corridor-Greater Bridgetown. Specifically, it is a qualitative survey of climate change vulnerabilities and human adaptation in the study domain that is underpinned by three research questions: 1) In what ways is Greater Bridgetown vulnerable to coastal hazards? 2) What are the human dimensions of this vulnerability? and 3) What are the associated human adaptations? We apply a fourcomponent adaptive urban governance framework to explore the role of the city's historical development, urban morphology, national-level institutions and relevant government and other stakeholder initiatives in shaping, reducing and/or increasing vulnerability to coastal hazards. The paper relates primarily to the governance dimension of the risk reduction framework articulated by the Intergovernmental Panel on Climate Change. In totality, a case is presented that highlights Greater Bridgetown's capacity for coastal/urban resilience, but which cannot be maximized without institutional prioritization of vulnerability, increased stakeholder "buy-in" and participation, along with significant investment in adaptation and the protection of valuable coastal infrastructure. The findings are of relevance to human adaptation within coastal cities of small island developing states.

Keywords: Caribbean, city, human adaptation, global climate change, inundation, resilience

\section{INTRODUCTION}

Climate change is expected to have a global impact, but it is well understood among climate change scientists that coastal cities in small island developing states (SIDS) in the Caribbean stand to be among the most climate-impacted in the world (Mycoo and Donovan, 2017). SIDS across the globe face several climate-related hazards that place their resources, populations and assets at serious risk (Robinson, 2017; Robinson, 2018; Hay et al., 2019). The level of exposure to climate hazards varies from territory to territory based on factors such as population distribution, island type, and topography, all of which provide a framework when considering vulnerability (Forbes et al., 2013). Several studies on the Caribbean confirm their settlements have been impacted by sealevel rise (SLR), heavy precipitation events, tropical cyclones, and storm surges, among other climate 
risks (Nurse et al., 2014; Cashman and Nagdee, 2017; Mycoo and Donovan, 2017; Mycoo, 2018). At the century scale and if adaptation is not pursued, the vast majority of low-lying islands, coasts and communities will encounter substantial risk from coastal hazards regardless of their level of development (Oppenheimer et al., 2019). Oppenheimer et al. (2019), p. 48 indicated that "even a small increase in mean sea level can significantly augment the frequency and intensity of flooding. This is because SLR elevates the platform for storm surges, tides, and waves, and because there is a log-linear relationship between a flood's height and its occurrence interval." Other studies suggest that the impact of sea-level changes on the settlements and infrastructure of small islands is proportionately greater than larger landmasses in part because of longer coastlines per unit of land area (Nunn and Kumar, 2018). In SIDS, major settlements tend to be located on the coast making them more exposed and more sensitive to climate-related hazards. For example, capital cities in the insular Caribbean are located on the coast and the majority are port cities (Cashman and Nagdee, 2017). Apart from high urban densities, the level of urbanization is very high in coastal areas in the Caribbean given that the population is attracted to flat lands, which generally cost less to build on when compared with hilly areas (Mycoo and Donovan, 2017; Mycoo, 2018).

Climate change has increased the intensity and spatial patterns of coastal hazards faced by Caribbean cities such as Bridgetown (Barbados), Georgetown (Guyana), Port of Spain (Trinidad and Tobago), Kingston (Jamaica), and Castries (St. Lucia) (Mycoo, 2014; Mycoo, 2017; Mycoo and Donovan, 2017). These cities are all located on the coast and the coastal hazards experienced include SLR, heavy precipitation events, tropical cyclones, and storm surges, and flooding. Based on various SLR models, it is projected that almost all coastal infrastructure in the Caribbean, including port and harbor facilities, will experience inundation in the future (Nurse, 2015; Cashman and Nagdee, 2017; Nurse, 2017). Climate-driven impacts on island infrastructure have been experienced for some time and are likely to become more widespread and more economically challenging in the next few decades (Robinson, 2017; Monioudi et al., 2018). Coastal flooding where there is a high concentration of population, infrastructure and economic assets, in particular, presents individuals, households, communities, and policy- and decision-makers in the region with numerous challenges, including effectively adapting to its impacts.

A systematic review of climate adaptation actions across all SIDS by Robinson (2020a) concluded that climate change impacts and adaptation responses in Caribbean SIDS are understudied. This paper seeks to help close this research gap. It qualitatively surveys climate change vulnerabilities in Greater Bridgetown (Barbados' capital city and its urban corridor) in seeking to understand human adaptation to coastal hazards (SLR, storm surges and flooding) within a SIDS context. We see human adaptations as the adjustments of human systems in response to actual/expected climatic stimuli, or their effects or impacts, that moderate harm, or exploit beneficial opportunities associated with climate change (IPCC, 2014, p. 1758). Three research questions underpin our enquiry: 1) In what ways is Greater
Bridgetown vulnerable to coastal hazards? 2) What are the human dimensions of this vulnerability? and 3) What are the associated human adaptations? A four-component adaptive urban governance framework is applied to explore the role of the city's historical development, urban morphology, nationallevel institutions and relevant government and other stakeholder initiatives in shaping, reducing and/or increasing vulnerability to coastal hazards. The remainder of the paper is divided into four main sections. In the first section, materials and methods used are presented. Within this, Barbados' geography and its vulnerability to coastal hazards are covered. The adaptive urban governance framework is described, as well as how data were collected and analyzed. The second section presents the results, following the application of the adaptive urban governance framework, and which are organized according to the framework's four components. In the third section, presents a discussion in view of the three research questions. The fourth and final section highlights the paper's major empirical insights, which are that 1) vulnerability to coastal hazards in an urban landscape is linked to the city's historical development (temporal scale), and to its urban morphology (spatial scale), 2) that this vulnerability is further linked to its governance, particularly the institutions, laws, policies and plans that are in force, 3) that this vulnerability is significantly reduced where there are synergies between formal and informal governance, and 4) socio-political engagement is an essential component of human system adaptation in an urban landscape. Based on these insights, this paper contributes to the discourse on global responses to climate change and helps highlight the relevance and urgency of human adaptation within coastal cities in SIDS.

\section{MATERIALS AND METHODS}

\section{Barbados' Geography and Its Vulnerability to Coastal Hazards}

Barbados is a small island in the Caribbean with a land mass of $430 \mathrm{~km}^{2}$. It is one of the top 20 most densely populated countries in the world with an estimated 2020 population of 287,375 persons and a density of 668 persons per $\mathrm{km}^{2}$ (see Figure 1). Topographically, it is a relatively flat island-the highest point is $334 \mathrm{~m}$ above sea-level at Mount Hillaby in the Scotland District-this makes its coastal zone vulnerable to SLR, storm surges and flooding. The projections of higher sealevels and increased tropical storm activity are expected to increase storm surge frequency and intensity. The main impact of storm surge is flooding, and because of Barbados' generally low-lying topography, it has been estimated that storm surge flooding events could extend over 150-300 m inland (Nurse, 2011). Barbados experiences flooding during the rainy season (June-November) when heavy precipitation over a short period places pressure on drainage channel capacity to cope with rapid surface water runoff, but storm surges also contribute to flooding, though mainly in coastal areas. On November 29, 2016, for example, the island experienced severe flooding resulting from a combination of a trough system and the Inter Tropical Convergence 


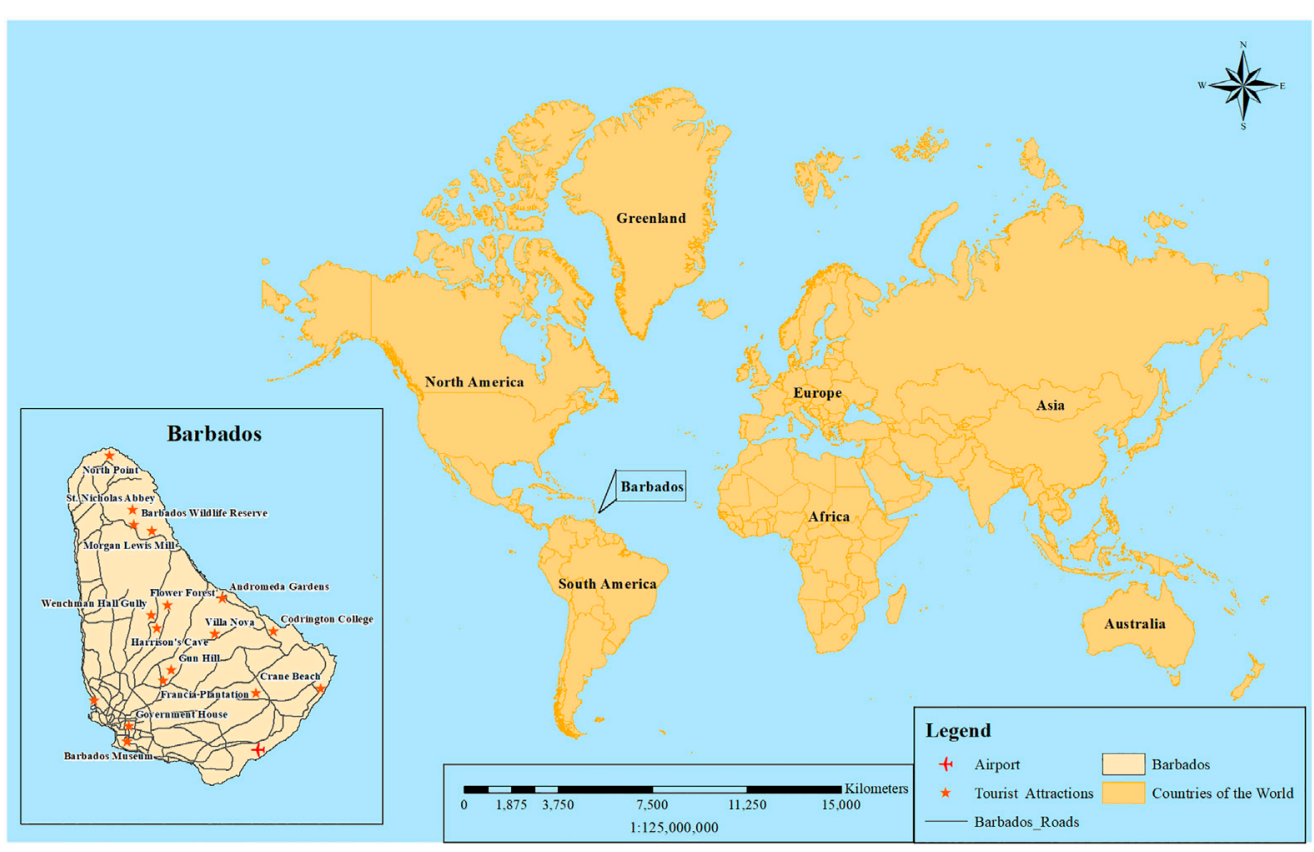

FIGURE 1 | Map of Barbados in relation to major geographical regions of the world (source: Rajesh Doodlal).

Zone, which generated intense showers lasting for just a few hours. The rapid onset and speed of travel of water from the central regions to the coast provided evidence of the vulnerability of infrastructure and settlements to the impacts of extreme events. There were several reports of property inundation and damage to vehicles where culverts were inadequate to channel this magnitude of storm water along regular courses to outfalls along the shoreline (Government of Barbados, 2018).

The majority of the country's population, coastal infrastructure and human settlements are located in the Low Elevation Coastal Zone (LECZ), which is the land area that is contiguous to the coastline up to a $10 \mathrm{~m}$ rise elevation. With rapid urbanization occurring within Barbados' LECZ, the country is especially vulnerable to SLR, storm surges and flooding. An estimated $18 \%$ of land mass in Barbados forms a part of the LECZ. Approximately 47,000 persons and 24\% of human settlement occupies this zone (Columbia University, 2011). The concentration of socio-economic infrastructure within the LECZ multiplies the vulnerability of the economy to climate change and its impacts. Flooding, in particular, is a major risk for persons living in Barbados' coastal zone-it impacts the health and safety of the population, as well as the security of freshwater supplies (Cashman et al., 2010), buildings and infrastructure. Historical flood records reveal that social, protective and institutional facilities such as churches, cemeteries, government buildings, post offices, petroleum storage facilities, police stations and schools have all been damaged by flood waters. Infrastructure such as the Port of Bridgetown, bus terminals, and power stations are also affected annually by flood waters. Major transportation arteries, for example, Highway 1 and Highway 7, two of the island's coastal highways that run along the north and southeast urban corridor extending from Bridgetown, are located in the LECZ, and in several areas, are especially vulnerable to SLR, storm surges and flooding. Figure 2 shows Holetown and Trent which are in the LECZ and climate change 25-year flood events and impacts based on various climate change scenarios.

With the impact from flooding and other natural and human factors, economic growth has been largely subdued over the last few years. In 2018, the Barbadian economy slipped into recession (Economic Commission for Latin America and the Caribbean (ECLAC, 2019). Nevertheless, tourism continues to be the economic mainstay, resulting in an increased dependency on a climate-sensitive sector. In 2018, this sector accounted for $22 \%$ of Barbados' gross domestic product (Government of Barbados, 2018). Tourism facilities such as hotels, guest houses, restaurants, bars and beachfront properties are located in areas prone to SLR, storm surges and flooding (Mycoo, 2006; Cashman et al., 2012; Mycoo and Chadwick, 2012; Scott et al., 2012; Mycoo, 2014). The hotels in Barbados, especially the larger ones, are on average located within the LECZ, which is consistent with the 1 in 100 inundation zones, placing them at risk of major structural damage associated with SLR, storm surges and flooding. Earlier studies reveal that approximately $90 \%$ of the island's hotels are located within $1 \mathrm{~km}$ of the high water mark and less than $20 \mathrm{~m}$ above sea-level (Belle and Bramwell, 2005; Dulal et al., 2009). Other studies, however, show that an estimated $50 \%$ of the hotel rooms in Barbados are at risk from a Category 3 hurricane because of their proximity to the mean sea-level. Becken and Hay (2008) estimate replacement costs of hotels could be up to US $\$ 550$ million. Although its geographic location is an advantage in that it lies outside the Atlantic hurricane belt, the island does 


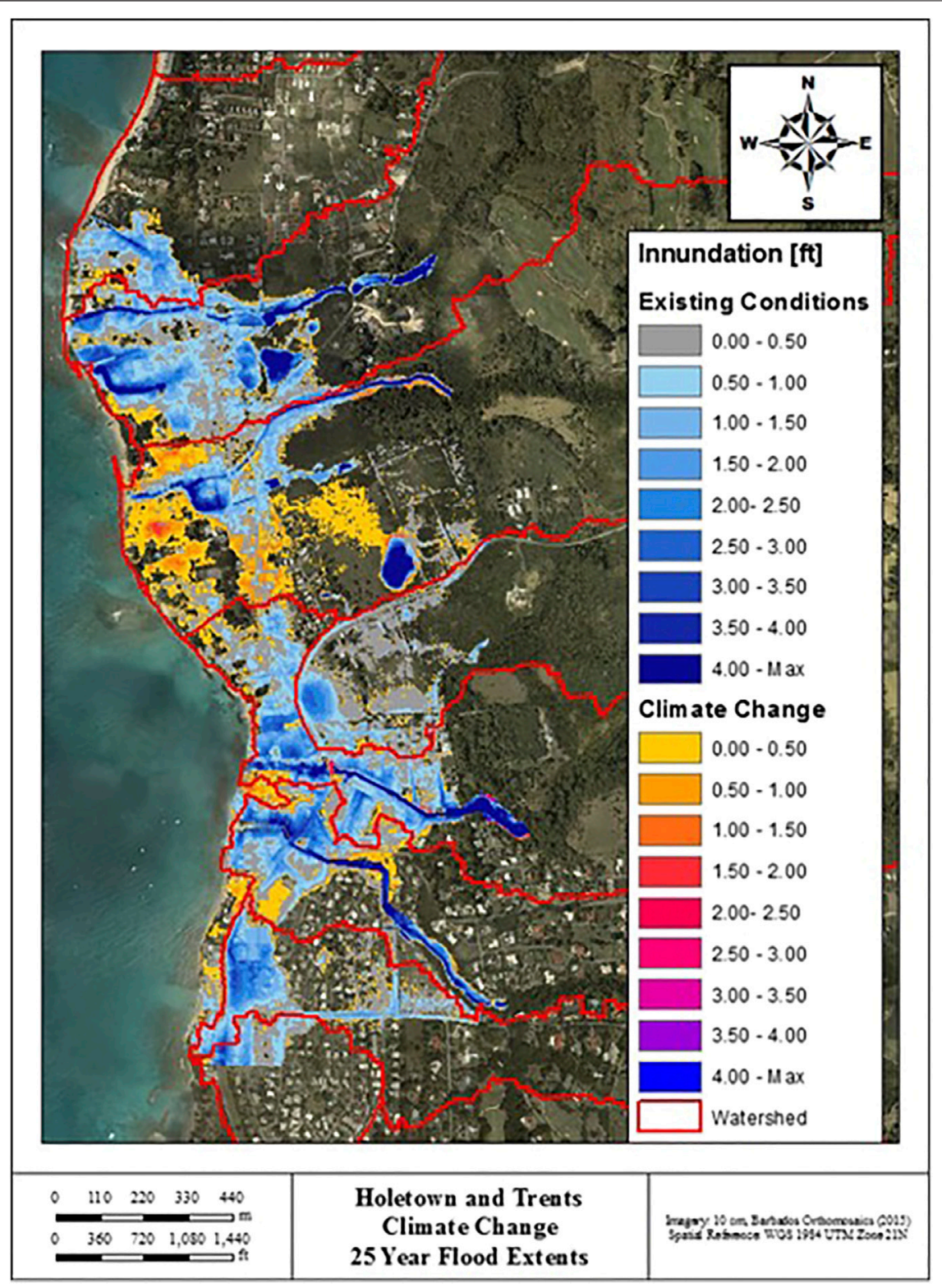

FIGURE 2 | Low Elevation Coastal Zone and Flooding in Holetown and Trent based on Climate Change Scenarios (source: Baird 2016).

not experience hurricanes as frequently as other Caribbean islands, but it is nevertheless exposed to major storms (Nguyen and Robinson, 2019).

\section{Theorizing Vulnerability to Coastal Hazards in a Small Island Developing States Context}

The demographic characteristics of Barbados are unique in contrast to other Caribbean islands in terms of population density, and the percentage of the population living in urban areas and along the coast. An estimated $44 \%$ of the population lives in urbanized areas, with the majority of persons settled in Bridgetown-a coastal city. The remaining population lives in other coastal areas, towns and villages, especially those located on the south and west coasts of the island (Government of Barbados, 2018). Currently, the majority of the population lives within three coastal parishes on the south-east, south and west coasts of the island which also support the four main urban centers-Bridgetown, Speightstown, Holetown and Oistins. Further, $25 \%$ of the population lives within $2 \mathrm{~km}$ of the coast in an "urban corridor," which runs along the entire length of the west and south coasts, and the parishes of St. Phillip, Christ Church, St. Michael, St. James, and the southern reaches of St. Peter. These areas constitute Greater Bridgetown (See Figure 3).

To understand Greater Bridgetown's vulnerability to coastal hazards (SLR, storm surges and flooding) and the associated human system adaptations, we apply an adaptive urban governance framework. Urban governance systems need to be 


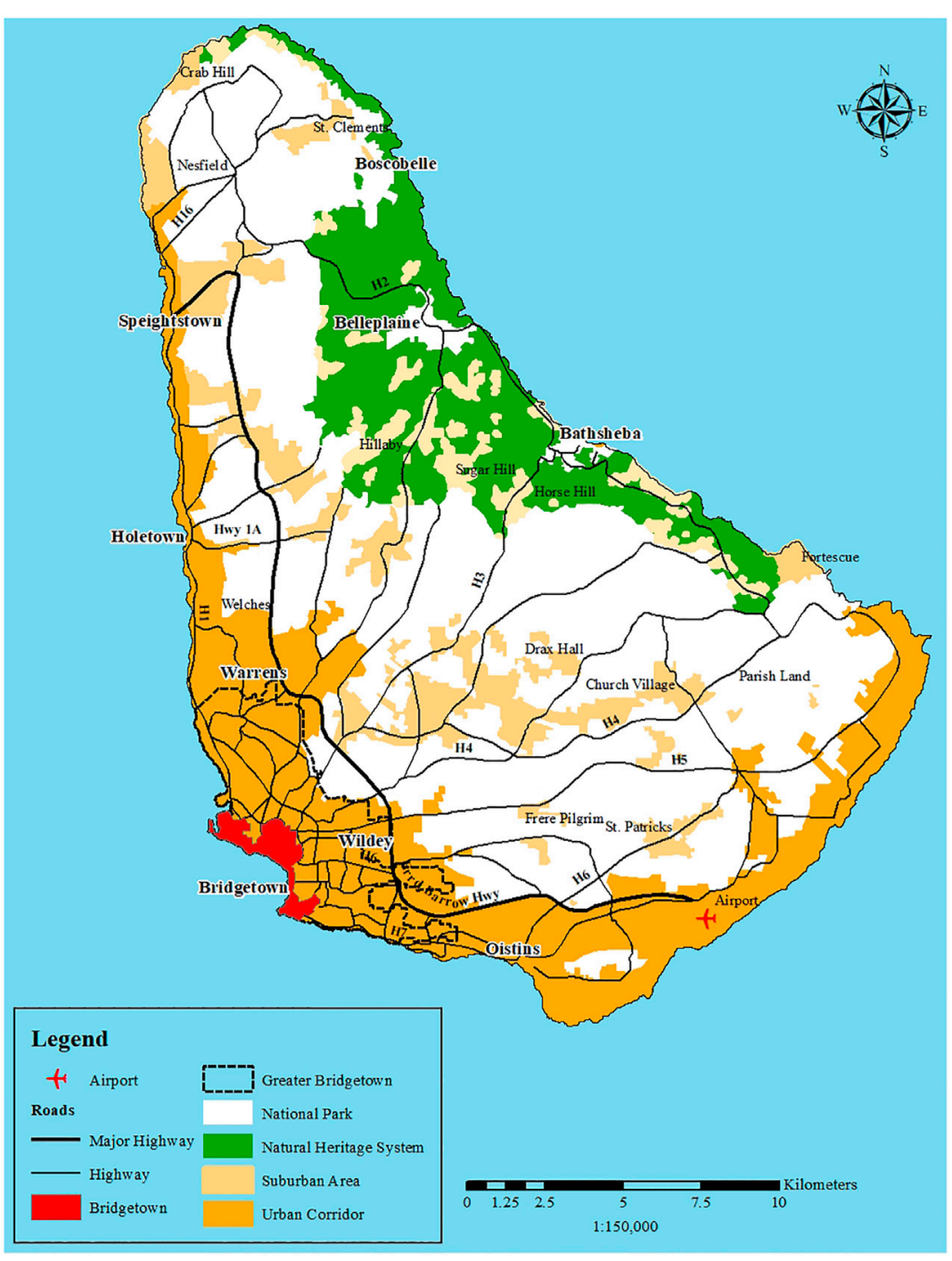

FIGURE 3 | Map showing the Four Main Urban Centers which constitute Greater Bridgetown (source: Rajesh Doodlal).

adaptive in order to deal with emerging uncertainties, dynamics, and pressures, including those related to climate change (Patterson and Huitema, 2019). Here, we understand "governance" as referring to the "institutional arrangements which shape actors' decisions and behavior, including the exercise of authority within groups or organizations" (Hatfield-Dodds et al., 2007, p. 4). Cities across the globe, as spatial groups, face multiple, interrelated and increasing climate change risks. In the Global South, including in the Caribbean, these risks arise within contexts that frequently involve substantial existing socio-economic inequalities and differential vulnerabilities (Bulkeley et al., 2014). Realizing adaptive urban governance systems requires that attention is paid to institutions, and in particular, processes of institutional innovation, if they exist. While scholars such as Patterson and Huitema (2019) develop multi-level heuristics to evaluate the role and effectiveness of institutions in urban adaptation governance, for example examining changes in institutional arrangements, rules-in-use and broader governance dilemmas, we reinterpret an earlier framework used in Birkmann et al. (2010). Our reinterpretation has four main components. Together, they offer an opportunity to conduct an in-depth analysis of urban adaptation processes, strategies and measures in Greater Bridgetown.

The application of the first component of our framework allows us to identify the "everyday" hazards in Greater Bridgetown through an interrogation of key threats, particularly in relation to the city's coastal assets. The second component explores the linkages between temporal and spatial scales, drawing attention to the historical, geographical and contemporary structural and non-structural adaptation processes, strategies and measures. This also enables us to comment on the robustness and flexibility of adjustments made in the human systems in response to actual/expected 
climatic stimuli, or their effects or impacts, that moderate harm, or exploit beneficial opportunities associated with climate change. The third component identifies the synergies between formal and informal governance processes and strategies. It allows us to address their potential effectiveness and secondary consequences as well as flag areas of potential conflict that could inhibit adaptation progress. The fourth component assesses the integration of expert and local knowledge. In a cursory way, we also look at tipping points and whether the urban landscape can cope and adapt to stresses beyond certain thresholds. Our framework, though it modifies Birkmann et al. (2010), takes an integrative approach to studying the primary urban governance system in Barbados, with broader implications for other coastal cities in the Caribbean as well as other SIDS regions.

\section{Data Collection and Analysis}

Primary and secondary data were collected between September 2019 and July 2020. We used a directed approach to analyze the content of text and image data in order to derive historic and contemporary indicators of coastal hazard risks (SLR, storm surges and flooding) in Greater Bridgetown. Content analysis is a widely used qualitative research technique (Hsieh and Shannon, 2005). The directed approach is part of a naturalistic paradigm and is one of three distinct approaches to content analysis-it starts with a theory or relevant research findings as guidance for initial codes (Hsieh and Shannon, 2005). In our case, we were guided by the adaptive urban governance framework we described above and, therefore, focused on identifying 1) "Everyday" hazards associated with the city's coastal assets, 2) Trends in the city's historical development and urban morphology that shape its vulnerability, 3) Formal and informal institutions, policies and plans for managing climate risk and adaptations, and 4) The role of and the adaptation actions undertaken by experts in the central government vis-a-vis local residents. Text analysis drew from government documents and United Nations publications. Government documents included policies and plans related to physical planning, climate change, coastal zone management, sustainable land management, and urban heritage and conservation. United Nations publications focused on the economic impact of climate change on tourism and other sectors. We conducted a site visit in May 2020 to collect photographic evidence of the impacts of coastal hazards as well as human adaptations along the urban corridor. Some of the images produced by Barbados' government agencies were used to analyze flooding in Greater Bridgetown. By studying how Greater Bridgetown's coast is vulnerable to SLR, storm surges and flooding, this paper contributes to an understanding of the city's climate vulnerability. In applying an adaptive urban governance framework and selectively drawing on key coastal assets to illustrate examples, this paper helps assess the various dimensions of Greater Bridgetown's coastal vulnerability in order to identify how the city and its population can increase their resilience to immediate and future climate threats.

\section{RESULTS}

\section{Framework Component 1: Acknowledging "Everyday" Hazards: Bridgetown and its Key Coastal Assets}

Bridgetown is located in the urban parish of St. Michael on the southwest corner of Barbados. The city has $4.28 \mathrm{~km}$ of coastline and has several coastal assets, including the Bridgetown Deepwater Harbor, Careenage, Carlisle Bay, and the UNESCO World Heritage Site (See Figure 4). Built in 1961, the Deepwater Harbor is the Caribbean's most trafficked deepwater harbor. In 2018 , the harbor facilitated $80 \%$ of Barbados' imports, 437 cruise ships, and approximately 830,000 cruise passengers (Hinkson, 2019). Located $1.75 \mathrm{~km}$ southwest of the Deepwater Harbor is the current Careenage-a commercial and recreational boat park, and iconic boardwalk that attracts locals and tourists (Google Earth, n.d.; Smith and Watson, 2008; Town and Country Development Planning Office (TCDPO), 2017). The city's main natural asset, Carlisle Bay, makes up nearly half of Bridgetown's total coastline and includes unique beaches and reefs (MPAtlas, n.d.). Tourism, residential, and government buildings line the Bay (Town and Country Development Planning Office, 2017a). Given the city's unique mix of old and new buildings, Historic Bridgetown, including its Garrison was declared a UNESCO World Heritage Site in 2011 (Government of Barbados, 2011). These four coastal assets are at risk of SLR, storm surges and flooding. The Bridgetown Deepwater Harbor and the Careenage are used to illustrate this point below.

The Bridgetown Deepwater Harbor represents the primary economic coastal asset of the city-it is most proficient for the transport of passengers from transnational cruise liners. The Harbor handles the most tourists per year in the Caribbean, supporting a vibrant tourism industry across Bridgetown (Government of Barbados, 2018). An assessment of the economic impact of climate change to Barbados' tourism industry found cruise ship facilities were damaged by [SLR], storm surge, coastal erosion and extreme weather events (Monioudi et al., 2018). These risks "will translate into costly [structural] repairs and potential loss of livelihoods. It was predicted that severe damage that requires such facilities to be completely closed will result in a decline in revenue from cruise tourism" (ECLAC, 2011). Increased average temperatures of $1.5^{\circ} \mathrm{C}$ will reduce the number of workable days for the Harbor along with other deepwater ports across the region (Monioudi et al., 2018). This assessment highlights an area of extreme concern regarding the accommodation and attraction of fewer tourists. Threats of coastal inundation from SLR, storm surges, flooding, and coastal erosion are obvious threats to the Harbor as it represents the intersection of a series of essential economic activities for the city of Bridgetown and its urban corridor.

The Careenage represents an area of high concentration of service infrastructure, including the Queen Elizabeth Hospital, the country's main hospital and two bus terminals. The local landmark and engineering antiquity are identified as an at-risk 


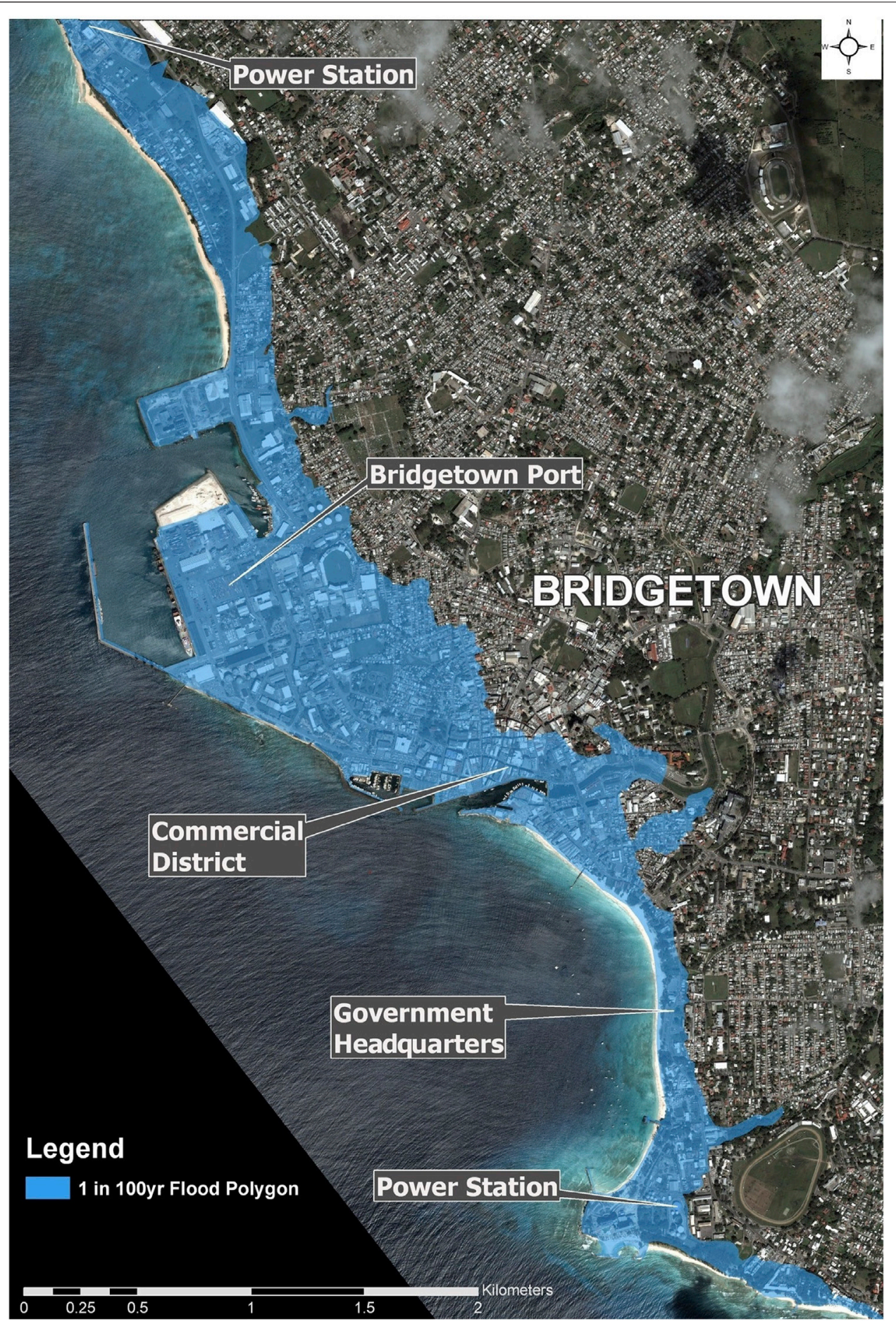

FIGURE 4 | Flood hazard map of Bridgetown showing some of the key coastal assets (Coastal Zone Management Unit, Government of Barbados).

coastal asset. The most direct impact of climate change on the Careenage and the downtown area is flooding (Government of Barbados, 2018). Inundation of this asset arising from SLR, storm surges, flooding, or extreme weather events has the potential to significantly disrupt economic and social activity. The lack of drainage infrastructure in the city, will intensify these issues , despite the city's Integrated Management Plan, which presents a case for "the redevelopment of the Constitution River for amenity and flood resilience purposes in the coastal floodplain of Bridgetown".

The results revealed the risk-focused decision by Bridgetown's institutions considers the future impacts, and the intensification 
of climate change in the city. Flooding is an understood risk across these and other coastal assets. As a result of this, building institutional capacity to provide and maintain adaptive flooding infrastructure is crucial for the city.

\section{Framework Component 2: Linking the Temporal and Spatial Scales: Historical Development and Urban Morphology Historical Development}

The land that Bridgetown is settled on was once a swamp, and prior to the arrival of British colonists, the area surrounding Carlisle Bay consisted of beach deposits and was covered with mangroves and other salt-tolerant trees and shrubs (Smith and Watson, 2008). Archaeological findings from the areas that are now Fontabelle, Spring Garden, and the Careenage indicate Amerindian settlement in and around Bridgetown dating back to $1623 \mathrm{BC}$. Amerindians in Bridgetown were subsistence farmers and fishers, utilizing slash and burn farming techniques that resulted in a landscape of small clearings of virgin forests, located close to the coastline. Archaeologists estimate that Amerindians numbered tens of thousands prior to the complete decimation of their population by 1,550 at the hands of Spanish colonizers.

Following the Spanish and Portuguese, who made stops on the island for water during the 16th Century, English ships landed in 1624 , and Bridgetown was settled in 1628, which marked the beginning of a period of British colonization, spanning four centuries and most notable for its maritime development. Bridgetown's Careenage offered a safe, natural harbor for vessels and hosting dock facilities for shipbuilding and maintenance. Initially, society centered around small-scale cultivation of cotton and tobacco; rapid growth of Bridgetown and poor urban planning followed immediately. The streets were not planned on a grid system like those of the Spanish colonial towns, and a uniform organization style for the town that existed in other British settlements in the Americas was non-existent (Smith and Watson, 2008).

In 1640 , the sugar trade was introduced to Bridgetown making it the center of international trade in the British Americas and one of its largest cities by the late 17th Century. The sugar trade brought even more rapid urban growth, and this, combined with Bridgetown's initial poor urban planning, resulted in limited sanitation, congested roads, disease, and fire. To address this, the Government introduced legislation to maintain public highways and formalized the city's boundaries in 1657 and 1660, respectively (Smith and Watson, 2008). However, fires continued to ensue. The most notable was the Fire of 1766, which damaged most of the town, and inspired the 1767 Rebuilding Act. The urban plan prepared following the Fire of 1766 greatly informed Bridgetown's present urban morphology-it catalyzed efforts to establish structural uniformity (Welch, 2004) and state control over urban development (Town and Country Development Planning Office, 2017a). From 1800 to 1885, Bridgetown served as the seat of government of the British colonies, and in 1881, the Barbados railway was completed from Bridgetown to Carrington, which contributed significantly to the continued development of the city (Town and Country Development Planning Office, 2017a).

In the early 20th Century, the arrival of the motor vehicle created issues for the narrow streets of Bridgetown. To address this, the Constitution River, Careenage, and remaining swamp areas were filled and then replaced by a channelized canal. This followed the construction of the Bridgetown Deepwater Port in 1961, which created a nexus for trade and communications away from the Careenage. With this construction came the conversion of vacant warehouses into offices, shops, and carparks, creating solid infrastructure for Bridgetown's emerging tourism industry. Barbados gained its independence in 1966, amid a period of high economic growth. Diversification of the economy from the $1950 \mathrm{~s}$ into the 1970s brought increased settlement to Bridgetown so much so that by 1980 , the population of Bridgetown represented almost half $(43 \%)$ of the country's total (Town and Country Development Planning Office, 2017a). Additionally, a protracted era of colonial settlement and sugarcane cultivation led to the depletion of much of its forested area leaving the island with approximately $84 \mathrm{~km}^{2}$ (19.5\%) of forests. Mangrove loss persisted in the post-colonial period as building activity went ahead on the south and west coasts, and so the only significant remaining mangrove is the Graeme Hall Swamp, which stands on approximately 20 ha (Schueler, 2016).

These historical developments-the settling and filling up of swamplands, unplanned streets, construction of the Deepwater Harbor to facilitate trade and communications, expansion of the modes of transport (e.g., rail) - have all resulted in development in Bridgetown closely aligned to the coast and being highly concentrated in the coastal zone (Government of Barbados, 2018). These leave the city exposed to various coastal hazards, including SLR, storm surges and flooding.

\section{Urban Morphology}

Bridgetown's history greatly informs its contemporary urban morphology. In the northwest areas of the city, the urban and historical core combines institutional, residential, and commercial infrastructure, including key coastal assets such as Carlisle Bay and the UNESCO World Heritage Site (Town and Country Development Planning Office, 2017d). The Bay Street Corridor runs adjacent to Carlisle Bay and connects the urban core to southern parts of Bridgetown and the colonial Garrison, the other half of the UNESCO World Heritage Site. Much of the city's tourism infrastructure and government buildings are located along this corridor (Town and Country Development Planning Office, 2017c).

Presently, urban planning is primarily guided by the Town and Country Development Planning Office through the Physical Development Plans it produces (1976, 1991, 2003, 2017). These plans outline development visions for specific areas in Barbados, including Bridgetown and its urban corridor (Government of Barbados, 2008; Downes et al., 2015; Town and Country Development Planning Office, 2017a; TCDPO, 2017a; TCDPO, 2017b). In addition to the key coastal assets, other types of development in Bridgetown's coastal areas include residences and historic sites. While most Barbadians live in chattel homes (i.e., small moveable wooden houses set on 
blocks or a groundsill rather than being anchored into the ground), which are typically occupied by lower-income residents, an increasing number are living in planned or multi-storey housing developments (Potter, 2000; McHardy and Donovan, 2016).

Bridgetown's early coastal location and urban morphology resulting from a concentration of population at the city center, and its major role as a port in the core-periphery relationship with England through which sugarcane exports were channelled, drew investments in infrastructure and buildings along the coastal city. This pattern was further entrenched in the postcolonial era when Government investments in offices, transportation upgrade and expansion, tourism and heritage and cultural buildings in the capital city increased, and later on extended to Greater Bridgetown. As a UNESCO World Heritage Site, Bridgetown blends historic and contemporary architecture. Given that the coastal zone is monopolized by the Heritage Site, which includes 30 distinct historic buildings or areas, the Government has increased efforts to redevelop and preserve these historic properties to enhance tourism and protect Barbadian heritage (Inniss, 2012; Downes et al., 2015; Town and Country Development Planning Office, 2017c). Such efforts increase the importance of protecting these areas from coastal hazards, including SLR, storm surges and flooding.

\section{Framework Component 3: Identifying Synergies Between Formal and Informal Governance: From Institutions to Projects Formal Governance: National-Level Institutions, Policies and Plans to Reduce Coastal Hazard Risk and Support Human Adaptation}

Barbados' government is highly centralized. It has a long history of town and country planning, along with a series of nationallevel institutions, policies and plans that govern the urban landscape. In 1965, the Barbados Town and Country Development Planning Office (TCDPO) published the Town and Country Planning Act (CAP. 240), which has guided development plans for the entire island over the past fifty-five years and includes provisions on planning control and its enforcement. Since then, the Act has been amended multiple times and was recently replaced by the Planning and Development Act, 2019, that was passed in the Senate in January 2019. This Act created a new government department: The Planning and Development Department, which houses the Planning and Development Board, the body responsible for the implementation of the policies outlined in the Act. The Act has five purposes, which encompass the facilitation of land development, the establishment of standards for development, and the incorporation of public participation and easy access to information.

Besides the Town and Country Planning Act (CAP. 240), the TCDPO is also responsible for publishing Physical Development Plans (PDPs). PDPs provide a policy framework for development planning; there are four published PDPs. According to the Barbados National Communication to the United Nations Habitat III Report, the initial PDP was enacted in 1976. This was followed by the second PDP in 1991, a third plan in 2003, and the fourth in 2017. The concept of sustainable development emerged in the 1991 PDP, and governed the 2003 plan entirely (Downes et al., 2015). The PDP of 2017 seeks to address the critical impacts of climate change on Barbados by utilizing appropriate policies and strategies to enable its population to thrive and remain resilient in the face of climatic changes (Town and Country Development Planning Office, 2017a). The need for transformational and foundational change to urgently take action to deal with climate change is articulated in this plan (Town and Country Development Planning Office, 2017a). The 2017 PDP clearly states that one of its main principles is the adoption of adaptation approaches which reflect national and sectoral challenges due to climate variability and climate change. It recognizes existing developmental pressures resulting from demographic changes and investor demands are changing land use patterns, but envision that these must be addressed within the broader context of climate change and sustainable development.

The 2017 PDP recommends several measures to support human adaptation to various coastal hazards in planning decisions, which departs from the hard engineering measures usually employed to minimize such impacts. These risk-informed land use planning measures include the adoption of tree preservation and replacement plans for all development in the Integrated Coastal Zone Management areas; Enforcement of the Tree Preservation Act; tree preservation in Cultural Heritage Conservation Areas; increasing forest and ground cover through the policies of the Natural Heritage System to increase infiltration and rainfall retention in the watershed and to reduce run-off; and improving agricultural practices to reduce run off. The role of individuals and communities in adopting these adaptation options is seen as integral.

In 1985, the Town and Country Planning Act (CAP. 240) presented one early instance of potential climate change adaptation policy by establishing coastal setback lines for construction (Coastal Zone Management Unit (Coastal Zone Management Unit, 2020a). This represented institutional/ human adaptation to changing coastal processes. Although the 1991 and 2003 PDPs prepared by the TCDPO introduced and emphasized sustainable development, more notable examples of institutionally promoted adaptation come from the Coastal Zone Management Unit which forms part of the Ministry of Health and Environment. The establishment of the CZMU is one of the earliest in the Caribbean region. The Unit released the Coastal Zone Management Act (1998), which called for a coastal zone management plan. The Integrated Coastal Zone Management Plan articulated comprehensive assessment, setting of objectives, planning and management of coastal systems and resources (Coastal Zone Management Unit, 2020a). The 1999 Integrated Coastal Management Plan for the West and South Coasts of Barbados highlighted the need to take into account global warming and its influence on sea level rise and increased storminess. It also advised that there was a need to distinguish between natural and human induced changes to ensure that policies were well-targeted to address their impacts (Coastal Zone Management Unit, 1999). The Integrated Coastal Zone 
Management Plan also laid the groundwork for various CZMU initiatives like the Coastal Infrastructure Program (2002-2009) and the Coastal Risk Assessment and Management Program (2011-present). The most recently updated draft CZMU plan (2020b) noted that adaptive capacity for climate change adaptation remained weak (Coastal Zone Management Unit, 2020b) and called for strengthening this capacity through a coordinated governance arrangement.

The TCDPO and the CZMU, in an effort to support human adaptation to coastal hazards, has produced hazard and risk assessments and maps related to, among other factors, longterm SLR, storm surges, flooding from marine and terrestrial events, including cliff instability, and tsunami impacts. Additionally, they facilitate human adaptation by ensuring that coastal management and development control decisions explicitly involve consideration of policies and management guidance under the "ridge-to-reef" concept, and specifically, the principles and practice of Integrated Watershed Management Planning and the Natural Heritage System identified in the Integrated Coastal Zone Management Plan. As part of the human adaptation approach to coastal hazard risk reduction, communities are engaged in managing one of the last remaining coastal wetlands at Holetown Lagoon. All of these measures involve a high level of stakeholder input, which is consistent with the inclusiveness espoused in the United Nations Sustainable Development Goal 11 (Make cities and human settlements inclusive, safe, resilient and sustainable).

A key government policy is (re)locating inland from the coast-this has been a form of human adaptation to both coastal erosion and flooding, which has been in practice over several decades. Barbados has a national statute, which predates climate change discussions, that established a minimum building setback for all new buildings along sandy coasts of $30 \mathrm{~m}$ from the mean high-water mark. Along cliffs, the setback is $10 \mathrm{~m}$ from the under portion of the cliff. For Barbados, one objective is to ensure that built developments are located away from the zone of risk where SLR, storm surges and flooding occur (Mycoo, 2006). Cognizant of the importance of knowledge awareness among individuals and communities in adapting to climate change, the TCDPO and the CZMU more recently have indicated that applications for major developments or change of land use within $30 \mathrm{~m}$ of the coast will be subject to an Environmental and Social Impact Assessment and other supporting or technical studies, subject to the satisfaction of the Chief Town Planner or his/her designate (Town and Country Development Planning Office, 2017a). In considering such applications, the TCDPO will act on advice provided by the CZMU and the Ministry of Public Works. It may also impose conditions of approval such as maintenance requirements. Here, stakeholder input will be a key feature of policy- and decision-making.

The current TCDPO PDP (Town and Country Development Planning Office, 2017b, p. 57) provided detailed guidelines for individuals, communities and investors to safeguard their assets from coastal hazard impacts. All development applicants within Flood Susceptible Areas will prepare, to the satisfaction of the Ministry responsible for drainage, a hydrologic design study as part of the supporting documentation for development proposals.
The purpose of this design study will be to assess the suitability of the development proposal to withstand projected flooding events on the site and to propose flood-proofing measures (Town and Country Development Planning Office, 2017b). Within Engineered Floodline Areas, new developments will not be permitted unless they can demonstrate that potential flooding can be contained using proposed flood proofing measures. Within Observed Flooded Areas, new developments will also not be permitted unless the stormwater management deficiencies within the area have been corrected to the satisfaction of the Ministry responsible for drainage, the Environmental Protection Department and Ministry of Health (Town and Country Development Planning Office, 2017a). In 100-year Floodline Areas, any new development or redevelopment areas will be designed with appropriate flood protection measures such as minimum freeboard elevation and prescribed limits to habitable space of building elements above flood levels (Town and Country Development Planning Office, 2017a). Development applications within the 100-years Floodline Area will be reviewed by the TCDPO based on the risk level and to determine whether an environmental and social impact assessment will be required. As part of the assessment, the applicant may be required to prepare and submit vulnerability assessments that explicitly identify the potential risks and mitigation measures acceptable to the Chief Town Planner. The environmental and social impact assessment process will take into consideration the impact of climate change and climate variability on the proposed development, and the development's influence on ecosystem processes and provisioning services (Town and Country Development Planning Office, 2017a).

Although there appears to be a sufficient amount of institutional interaction with respect to urban planning and some interaction with human adaptation, there remain some tensions and gaps between these institutions and their policies, most of which are highlighted in the TCDPO's Draft Green Paper on Planning Law Reform. First, it finds that there are issues surrounding the legal status of PDPs. Second, the Draft Green Paper calls for more clarity on the ways in which the Coastal Zone Management Act and the Town and Country Planning Act should interact and the role of the CZMU in decision-making on planning applications (Town and Country Development Planning Office, 2017a). Such tensions have particular significance to the coastal assets that are referenced in this paper because each asset falls within the coastal zone and, therefore, could be managed in accordance with both the Coastal Zone Management Act and the Town and Country Planning Act, potentially resulting in a mismanagement of development, and increased vulnerability because of overlapping jurisdictions. Third, the Draft Green Paper highlights a need for stronger provisions relating to the built heritage of Bridgetown, which is most likely a reference to Bridgetown's status as a UNESCO World Heritage Site (Town and Country Development Planning Office, 2017a). This holds particular relevance to the UNESCO World Heritage Site, since inadequate regulation of development in or around this asset could significantly increase its vulnerability to climate change. 
TABLE 1 | A Summary of Bridgetown-specific initiatives.

\begin{tabular}{|c|c|c|c|c|}
\hline Adaptation Initiative & Climate risk addressed & Stakeholder & Adaptation Typology & Coastal Asset \\
\hline $\begin{array}{l}\text { Constitution River Project } \\
\text { Phase III- Flood Mitigation } \\
\text { Works (2015) (Bahamas } \\
\text { Trade Info, 2017; Nation } \\
\text { News, 2015) }\end{array}$ & Flooding & $\begin{array}{l}\text { Caribbean Development } \\
\text { Bank (CDB), Barbados } \\
\text { Tourism Investment, Inc. } \\
\text { (BTI) }\end{array}$ & Implementation/Management & $\mathrm{n} / \mathrm{a}$ \\
\hline $\begin{array}{l}\text { Coastal engineering } \\
\text { infrastructure, including } \\
\text { revetments and sea walls } \\
\text { (1995, 2014) (Coastal Zone } \\
\text { Management Unit, 1998; } \\
\text { Government of Barbados, } \\
\text { 2011; Flour Mill, St. } \\
\text { Michael, Barbados, n.d; } \\
\text { Thompson, 2013) }\end{array}$ & $\begin{array}{l}\text { Coastal erosion and } \\
\text { inundation, sea-level rise, } \\
\text { protection from extreme } \\
\text { storm surges }\end{array}$ & $\begin{array}{l}\text { Coastal Zone Management } \\
\text { Unit (CZMU), Infra, Inc., } \\
\text { Inter-American } \\
\text { Development Bank (IDB) }\end{array}$ & Implementation/Management & $\begin{array}{l}\text { Bridgetown Deepwater } \\
\text { Harbour } \\
\text { Historic Bridgetown and its } \\
\text { Garrison }\end{array}$ \\
\hline $\begin{array}{l}\text { Historic Bridgetown and its } \\
\text { Garrison: Action Plan for } \\
\text { Risk Management (2011) } \\
\text { (Government of Barbados, } \\
\text { 2011) }\end{array}$ & $\begin{array}{l}\text { Flooding, sea level rise, } \\
\text { frequent and intense } \\
\text { storms, high levels of } \\
\text { rainfall }\end{array}$ & $\begin{array}{l}\text { CZMU, Department of } \\
\text { Emergency Management, } \\
\text { Government of Barbados }\end{array}$ & Implementation/Management & $\begin{array}{l}\text { Historic Bridgetown and its } \\
\text { Garrison }\end{array}$ \\
\hline $\begin{array}{l}\text { Aquarius Watersports } \\
\text { Summer Camp (2005-2006 } \\
\text { and 2018) (ICRI, 2018; SGP } \\
\text { The GEF Small Grants } \\
\text { Programme, n.d) }\end{array}$ & $\begin{array}{l}\text { Marine ecosystem loss and } \\
\text { damage }\end{array}$ & $\begin{array}{l}\text { Barbados Marine Trust, } \\
\text { International Coral Reef } \\
\text { Initiative, Small Grants } \\
\text { Programme through the } \\
\text { Global Environment Facility }\end{array}$ & $\begin{array}{l}\text { Education and Knowledge } \\
\text { Management }\end{array}$ & Carlisle Bay \\
\hline $\begin{array}{l}\text { Caribbean Youth } \\
\text { Environment Network } \\
\text { Barbados (CYEN) (1993- } \\
\text { present); Barbados Today, } \\
\text { 2019) }\end{array}$ & $\begin{array}{l}\text { Marine ecosystem loss and } \\
\text { damage }\end{array}$ & CYEN, Ocean Conservancy & $\begin{array}{l}\text { Education and Knowledge } \\
\text { Management }\end{array}$ & Carlisle Bay \\
\hline $\begin{array}{l}\text { Carlisle Bay Marine Park } \\
\text { (1997-2003) (CZMU, n.d. } \\
\text { (b); MPAtlas, n.d; UN } \\
\text { ECLAC, } 2011\end{array}$ & $\begin{array}{l}\text { Erosion, marine ecosystem } \\
\text { damage from pollution }\end{array}$ & CZMU & Implementation/Management & Carlisle Bay \\
\hline
\end{tabular}

\section{Formal Governance: Programmes and Projects to Reduce Coastal Hazards and Support Human Adaptation}

Flooding due to storm surges has had a large influence on residential, commercial and tourism assets, with estimated damages in the range of approximately US $\$ 1.5$ billion for the 100-years condition (Coastal Zone Management Unit, 2020a). Some of the greatest damage has been in the Bridgetown area, yet most efforts to address coastal vulnerability to climate change in Barbados occur outside of Bridgetown. For instance, in the late 1990s to early 2000s, Barbados built several structures, such as boardwalks or groynes, to reduce coastal erosion. However, these structures are primarily located north or southeast of Bridgetown in Holetown and Rockley Beach, respectively (Mycoo, 2014; Coastal Zone Management Unit, 2020a). Furthermore, the implications of national vulnerability initiatives for climate risk reduction in Bridgetown are unclear. As an example, the Coastal Conservation Feasibility and Pre-Investment Study (1991) and Coastal Risk Assessment and Management Program (2011-present), funded by the Inter-American Development Bank, evaluated and addressed coastal climate hazards to Barbados' south and west coast (Mycoo and Donovan, 2017). While Bridgetown is located on the southwest coast, it is unclear whether these initiatives identified climate vulnerabilities in or specific risk reduction actions for the city. Therefore, national efforts to address coastal climate risks lack specificity to coastal vulnerability in Bridgetown and its adjoining urban corridor.

Over the years, however, there have been programmes and projects aimed at reducing coastal hazards and providing support for human adaptation in Greater Bridgetown. In 2015, the Caribbean Development Bank provided a US\$7 million loan to the Government to upgrade the Constitution River, the primary channel that drains Bridgetown. The project's objective was to reduce flooding in Bridgetown through drainage channel dredging and rock armouring (Caribbean Development Bank, 2015). The Government is currently executing the Water Resource Management and Flood Resilience Climate Change Program, funded with assistance from the United States Agency for International Development (Government of Barbados, 2018). Additionally, there are a few Bridgetownspecific vulnerability initiatives which address climate risk to the coastal assets we reference in this paper (See Table 1). These initiatives can be classified per Robinson's (2017, p. 681) adaptation typologies for SIDS, which were developed to categorize similar climate adaptations and assess adaptation trends across SIDS. The five typologies are: 1) observation and 
assessments, 2) planning, institutions, and policies, 3) implementation and management, 4) monitoring and evaluation, and 5) education and knowledge management.

In Bridgetown proper and as indicated in Table 1, vulnerability initiatives (a) are mostly categorized under the "implementation and management" typology and (b) address flooding and marine ecosystem loss. Flooding and coastal inundation present the most direct climate risk to the city and its coastal assets, and as a result the Constitution River Project (2016) and coastal engineering infrastructure are important vulnerability reduction efforts (Government of Barbados, 2018). The Constitution River Project aims to reduce urban flood risk by creating better drainage systems. However, given the project is approximately $1 \mathrm{~km}$ inland, it is unclear how the upgrades address vulnerability to these coastal assets. Additionally, using funding from the Inter-American Development Bank and private donors, specifically from the Barbadian construction company Infra Inc., Bridgetown has built seawalls at the Garrison and revetments at the Harbor to reduce physical threats of coastal inundation and storm surges (Government of Barbados, 2011; Thompson, 2013).

While vulnerability measures classified as "implementation and management" actions are hard infrastructure projects aimed at reducing flood and coastal inundation risk, initiatives classified under "education and management" address social vulnerabilities to climate change. The Aquarius Watersports Camp and the Caribbean Youth Environment Network Barbados (CYEN Barbados) organize outdoor recreation experiences or beach clean-ups at Carlisle Bay, respectively, to increase youth capacity to respond to marine ecosystem degradation (Aquarius Watersports Barbados, n.d.; Hinkson, 2019; Caribbean Youth Environment Network in Barbados, n.d.; SGP The GEF Small Grants Program, n.d.). Overall, Bridgetown's limited number of city-specific initiatives address some physical and social vulnerability to coastal assets.

Although Bridgetown has had multiple PDPs with implications for climate vulnerability reduction, few plans have been implemented. For instance, Barbados participates in the InterAmerican Development Bank's Emerging and Sustainable Cities Program, which supports Latin American and Caribbean cities in developing specific action plans to increase resilience (InterAmerican Development Bank, n.d). Yet, it has not developed a Sustainable Cities Plan, the barriers to implementation are unclear, and the lack of follow-through on the Emerging and Sustainable Cities Program and other development plans is likely limiting the number and effectiveness of Bridgetown-specific climate initiatives. With these restrictions, the role of these initiatives in reducing coastal vulnerability is ambiguous. On the one hand, the Aquarius Watersports Camp inspired participants to think critically about or pursue marine environment conservation (SGP The GEF Small Grants Program, n.d.). This suggests that, along with processes to draft the Planning and Development Act and develop heritage-based tourism, climate resilience efforts could also be increasing community engagement in Bridgetown-a significant shift given the city's historic lack of public participation. On the other hand, existing Bridgetown-specific initiatives fail to address climate risks at the Careenage. Additionally, only half the initiatives address flooding or coastal inundation, the largest threats to key assets. Therefore, these gaps suggest that vulnerability reduction efforts in Bridgetown are disconnected from the city's major climate risks.

\section{Informal Governance: Adapting Coastal Assets for Local Needs and Uses}

Research by Jaja et al. (2017) shows that, given that potential climate impacts are experienced more locally, it is important to focus community-based or social adaptation responses to identify actual climate impacts. In Barbados' urban corridor community efforts, social adaptation responses point to the climate change impacts that the population is most affected by such as flooding, erosion and storms. Climate change and associated coastal hazards impacting Greater Bridgetown have led to human adaptation in several ways where locals are adapting coastal assets for their needs and uses. Losses to coastal ecosystem services, infrastructure damage and threats to livelihoods due to climate change have promoted human responses to improve economic resilience. The island's tourism product focused in the past on beach tourism and catered to mainly tourists from the United Kingdom, and to a lesser extent, the United States (Lorde et al., 2011). Nature-based tourism, especially exploiting its coastal assets, including the beaches and coral reefs, has remained vital to economic survival, but the population has diversified into cultural and heritage tourism as a means of adapting to the impacts of climate change and to remain competitive in an ever-changing international tourism market (Richardson-Ngwenya and Momsen, 2017). With SLR and beach erosion occurring on the southwest coast, the designation of Bridgetown as a UNESCO World Heritage Site is strategic in reducing its dependence on beach tourism while simultaneously ensuring the preservation of historic buildings.

Another aspect of resident-led human adaptation in the Barbados context is the use of cultural traditions such as fish fry events to develop alternative livelihoods (Leslie, 2010). Small fish fry vendors, who tend to be mainly women from the community of Oistins, have self-organized and set-up stalls on Friday nights further inland from the coast where tourists can enjoy the local cuisine and delicacies, purchase arts and craft and participate in Barbadian and Caribbean entertainment (Leslie, 2010). This location and product diversification help minimize the vulnerability of small business operators to the vicissitudes of climate change such as SLR, storm surge and flooding. The women use their social capital formed through links with tour operators and hotels to promote their small business operations, especially the fish fry stalls (Richardson-Ngwenya and Momsen, 2017).

Human adaptation is also demonstrated in the actions taken by Oistins' fishers who are faced with high socio-economic vulnerability (Leslie, 2010). Many of their boats are usually uninsured against hurricanes and storms and they generally lack savings to absorb the cost of boat repair or replacement (Leslie, 2010). In response to livelihood threats from such events, fishermen have joined up with the women fish fry vendors, restaurants and rum shops to get catch sold so as to generate 


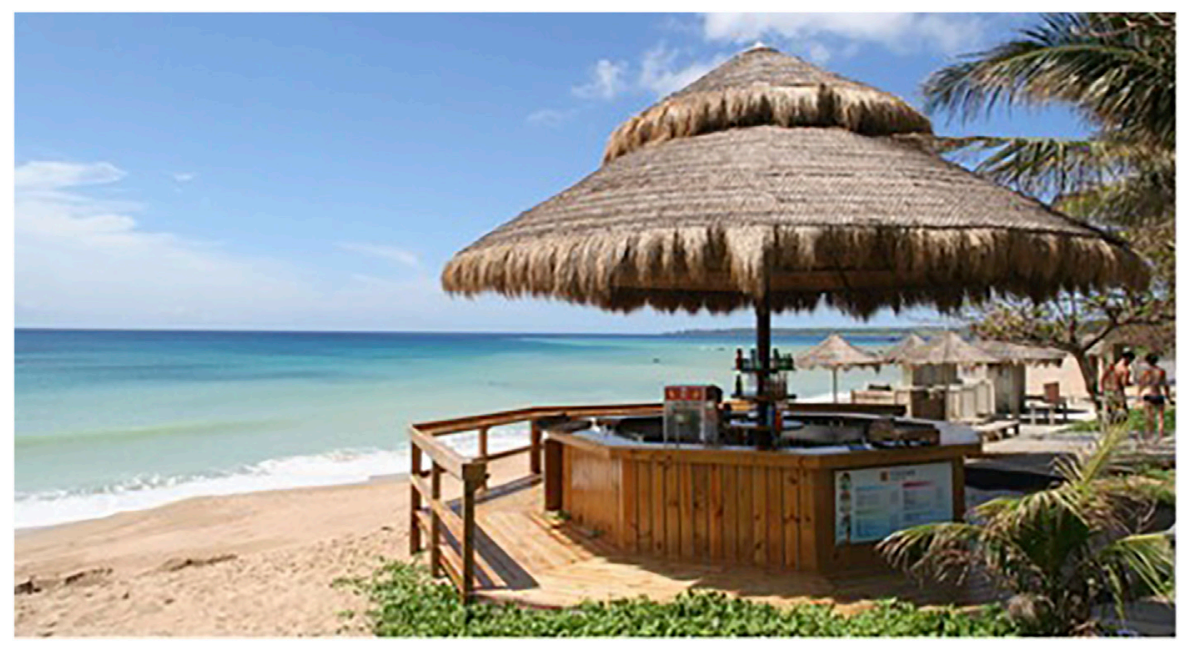

FIGURE 5 | A beach bar along Barbados' southwest coast.

income, but also to raise savings to provide relief during times of hardship as is often the case in the aftermath of such extreme events (McConney et al., 2012; Monnereau and Oxenford, 2017). This pattern of adaptation is consistent with the rest of the Caribbean where most small-scale fishers, especially the reefassociated shallow shelf fishers have one or more additional or alternate seasonal sources of income within the fisheries sector, or from other sectors, especially tourism and construction (see Gill et al., 2007; Mumby et al., 2014; Gill et al., 2019). For fishers, forming partnerships with the women fish fry vendors is a social safety net that provides access to income and livelihood opportunities when other sectors fail or are disrupted by extreme weather events (McConney et al., 2012).

Beach bars and restaurants situated along Barbados' southwest coast, which provide additional evidence of informal coastal asset adaptation, are impermanent structures that are built directly on the beachfront and are easily relocated if flooding from SLR becomes more severe (See Figure 5). Operators of these small businesses have adapted the structures along the lines of chattel houses (i.e. small moveable wooden houses set on blocks or a groundsill rather than being anchored into the ground) for which Barbados is well-known (Richardson-Ngwenya and Momsen, 2017). This allows the structures to be disassembled (along with the blocks) and moved from place to place. Although the beach bars and restaurants are permitted at the beachfront to promote livelihoods associated with coastal tourism, their flexible structure inadvertently enables small business operators to adapt to coastal flooding and erosion by moving to higher ground.

\section{Framework Component 4: Integrating Expert and Local Knowledge: Transcending the Central Government and its Technocrats}

As Barbados' government is highly centralized, most human adaptation to coastal and other hazards has been coordinated by the central government, particularly through the TCDPO and the CZMU, within which the role of individuals and communities in adopting various adaptation options is seen as integral. Two examples will be recounted here. First, the 2017 PDP, released by the TCDPO, recommends several measures to support human adaptation to SLR, storm surges and flooding in planning decisions, which departs from the hard engineering measures usually employed to minimize such impacts. These risk-informed land use planning measures include the adoption of tree preservation and replacement plans for all development in the Integrated Coastal Zone Management areas. Second, as mentioned earlier, the TCDPO and the CZMU have indicated that applications for major developments or change of land use within $30 \mathrm{~m}$ of the coast will be subject to an Environmental and Social Impact Assessment and other supporting or technical studies subject to the satisfaction of the Chief Town Planner or designate. These two examples underscore the centrality of the government and its technocrats in human adaptation to coastal hazards; they also signal a recognition of stakeholder input being a key feature of policy- and decision-making.

Much emphasis has been placed on top-down or planned human adaptation, which also has the tendency to undermine the capacity for organized responses that are catalytic in transforming societies from within. However, there is scope to transcend the central government and its technocrats, and increasingly integrate local communities and their knowledge into human adaptation. In fact, individuals, communities and private entrepreneurs are progressively more engaged in finding their own homegrown solutions in adapting to climate change impacts such as flooding. This is illustrated by the fish fry events and the temporary construction of beach bars and restaurants described above. Additionally, although Bridgetown has historically lacked socio-political engagement (Pelling, 2003; Pugh, 2006; Pugh, 2013), the tide may be turning. During the drafting of the 2019 Planning and Development Act, the Government placed an emphasis on public participation, and hosted a stakeholder 
discussion in July 2018 for professionals involved in the planning process (Joy, 2018). While the discussion was live-broadcasted and it was requested that any public input be emailed or mailed, it is unclear whether there were forums or meetings where the public could discuss the Bill and be informed of it in person. It is clear that the Barbados Government is making attempts at increasing participation, but the absence of prominent citylevel institutions could be hampering greater adaptation action (see Robinson, 2020b), as local institutions can be better informed by the public, and therefore minimize the risk of misaligned policy.

\section{DISCUSSION}

In this section, we discuss the above results in view of the paper's three research questions.

\section{Research Question 1: In What Ways is Greater Bridgetown Vulnerable to Coastal Hazards?}

We found that flooding in Barbados as a whole, and in Bridgetown specifically, is attributable to anthropogenic pressures such as built development arising from urbanization as well as rising sea-levels and storm surges resulting from climate change. A long history of colonial settlement and sugar cane cultivation resulted in substantial forest depletion leaving the island with approximately $84 \mathrm{~km}^{2}(19.5 \%)$ of forested area. Bridgetown's early coastal location and urban morphology resulting from a concentration of population at the city center, and its major role as a port in the core-periphery relationship with England through which sugarcane exports were channelled, drew investments in infrastructure and buildings along the coast. This pattern was further entrenched in the postcolonial era when government investments in offices, transportation upgrade and expansion, tourism and heritage and cultural buildings increased in the capital city and later on, Greater Bridgetown. As noted earlier, in the post-colonial era, many mangrove forests have been cleared to accommodate development along the south and west coasts and the only significant remaining mangroves are the Graeme Hall Swamp, which stands on approximately 20 ha. Forests and mangrove denudation significantly contribute to the population's increasing vulnerability to coastal hazards as forests and mangroves provide ecosystem provisioning services such as flood mitigation. The population settled along coastal parts of Greater Bridgetown are vulnerable to flooding associated with heavy rainfall in the wet season, rising sea level and storm surges.

Studies conducted in 2015 showed that there were shifts in migration from Bridgetown to an urban corridor made up of suburban centers. This changing internal migration pattern may reduce the vulnerability of the population to coastal hazards. These studies found that despite some economic growth, Bridgetown is experiencing declining population density, and increasing poverty. In addition to high rates of vacant buildings in Bridgetown many residents were relocating to emerging suburban areas north or south of the city, like Holetown and Warrens (Downes et al., 2015; Seijas, 2015). Statistical evidence confirmed that from 2004 to 2016, population density fell from 330 persons to 260 persons per $\mathrm{km}^{2}$. Additionally, in 2010 , the population of Bridgetown was comparatively poorer than that of rural Barbados (Downes et al., 2015). These characteristics suggest that Barbadians are either abandoning Bridgetown for more desirable opportunities or quality of life in surrounding areas, or, as Downes et al. (2015) suggests, gentrification from coastal development is pushing some Barbadians out of the urban center. This is, in some respects, relieving human pressure on the coastal plain-it will also likely reduce human impacts should there be a major flooding event.

Hydrological studies confirm that flooding results from an interplay of time, location and space of climate change, climate variability, soil characteristics, vegetative cover, topography and land elevation. In SIDS, urbanization and development have given rise to new causes of flooding that magnify adverse societal effects. Traditionally, across the globe, engineering has been seen as a panacea for flood mitigation. Flood management has, until recently, emphasized investment and trust in constructed solutions that rely on structural robustness. As Cashman et al. (2012) p. 2 note, however:

\begin{abstract}
"This attitude has been changing, brought about by a number of factors including the apparent failure of hard engineering to prevent or at least contain flooding events. At the same time there has been a shift in public attitudes towards flood risks; no longer are they seen as acts of providence for which the government has only a minor responsibility. Increasingly, flooding is seen as the responsibility of the government to do something about. More and more communities that are at risk are demanding that they be protected. Meeting such expectations and demands while in theory would be technically feasible is in practice impossible given the financial resources that would be required. As a result, other approaches are being actively explored that accept and live with floods....and seek to place an emphasis on building resilience amongst stakeholders as a coping strategy.”
\end{abstract}

In Caribbean SIDS, including Barbados, while much emphasis has been placed on engineering solutions to climate change, there are examples of ecosystem based measures solutions that are being used by individuals, households and communities in response to climate change challenges. Nevertheless, extensive social networks, personal economic investments and political obstacles complicate effective human adaptation.

\section{Research Question 2: What are the Human Dimensions of This Vulnerability?}

Specifically, we found that the four coastal assets referenced in this paper-Bridgetown Deepwater Harbor, Careenage, Carlisle Bay, and the UNESCO World Heritage Site-are physically, economically, and socially vulnerable to various coastal 
hazards, including SLR, storm surges and flooding. Physically, these assets are located within the 100-year flood area; therefore, coastal inundation could lead to significant loss and/or damage (Town and Country Development Planning Office, 2017a). Economic vulnerability is illustrated by climate threats to the Bridgetown Deepwater Harbor. Wholesale and retail trade and tourism account for 34\% of Barbados' gross domestic product (Government of Barbados, 2018). Given that the Deepwater Harbor facilitates this robust trade and tourism economy, inundation or damage to the Harbor would hinder its ability to host cargo and cruise ships, thereby straining these vital sectors and Barbados' economy (Government of Barbados, 2018). Despite the extent of this climate risk, there is a mismatch with initiatives along with evidence to suggest that climate threats have not been a primary concern for Bridgetownspecific vulnerability reduction programmes. For example, the UNESCO World Heritage Site Action Plan for Risk Management intends to address climate-related flooding and storm surges through coordinated disaster responses (Government of Barbados, 2011). This suggests that disaster risk management is prioritized over reducing coastal climate hazards and risks, potentially weakening coastal climate responses in Bridgetown. However, the fact that climate is one of many considerations also suggests a holistic approach to climate vulnerability reduction in Bridgetown. Medina et al. (2019) note that future climate vulnerability strategies in Barbados should combine disaster risk management with long-term initiatives to strengthen coastal responses to climate change, further highlighting the strength of an integrated approach. However, given that 1) the Careenage remains uncovered by any initiatives specific to Bridgetown 2) major climate risks to the key assets (e.g., flooding and coastal inundation), are rarely first concerns of Bridgetown-specific initiatives, and 3) few climate resilience plans are implemented, serious challenges to reducing vulnerability remain. In summary, despite Bridgetown's efforts to reduce physical and social vulnerabilities to its coastal assets and surrounding areas, the failure by the government and stakeholders to address and prioritize the most significant climate threats and implement a wide variety of climate risk reduction or development programmes, has ultimately limited the city's ability to reduce coastal vulnerability to climate change and build coastal resilience. These institutional and social barriers highlight the human dimensions of vulnerability to climate change as people's lives, livelihoods and assets remain exposed to risks and are impacted by cascading climate change events such as flooding and storm surges.

\section{Research Question 3: What are the Associated Human Adaptations?}

We found that institutions in Bridgetown have traditionally been deployed to understand risks to people stemming from coastal hazards, especially flooding, and have been mandated to manage coastal development. Yet, a key finding is that the city's local institutions are weak and there is a divergence between the planning and implementation of risk-focused adaptations. Further, less emphasis has been placed on the adaptation to long-term risks for coastal assets and areas, and as a result, these assets and the people living on the coasts are quite vulnerable. The TCDPO and the CZMU represent two significant institutions that operate to manage risks regarding elements of the coastal assets discussed. In order for Bridgetown to transform alongside the pernicious risks of climate change, an institutional prioritization of adaptation and resilience building in both key coastal assets, and the institutions themselves is essential. Addressing coastal asset vulnerability will likely require improving or increasing levels of public participation. Pelling (2003) notes that poor public participation could result in misunderstanding or poor mismanagement of climate risks within coastal communities, thereby suggesting that Greater Bridgetown's characteristic lack of community engagement will likely create and/or increase social vulnerabilities. However, the current community engagement efforts through heritage preservation or heritage-based tourism development will likely help to alleviate climate vulnerability, especially to the key coastal assets. The city's focus on redeveloping historic sites will also likely increase the role of public participation in Bridgetown. For instance, in the UNESCO World Heritage Site's Management Plan, the "wider public" is listed as a stakeholder and several institutions, including the Barbados National Gallery and Barbados Museum and Historical Society, are tasked with gaining community "buy-in" for heritage preservation (Barbados World Heritage Committee, 2011, p. 47). Given the traditionally low socio-political involvement of Bridgetown's residents, helping to protect and enhance heritage sites could decrease previous ambivalence toward public engagement (Pelling, 2003; Inniss, 2012). Current community-based responses suggest human adaptation is prioritized according to the most critical climate hazard issues that impact on livelihoods. This is clearly illustrated in the building of mobile beach bars and the location of fish fry operations further inland from the coast, thereby protecting community investments, assets and livelihoods from flooding, erosion and storms.

Considering governmental and community-based responses, continuing to explore the role of public participation and human adaptations in the context of climate change in Greater Bridgetown will be important. The paper's finding that capacity for coastal/urban resilience cannot be maximized without institutional prioritization of vulnerability, increased stakeholder "buyin" and participation, along with substantial investment in adaptation and the protection of valuable coastal infrastructure, also has relevance for SIDS besides Barbados as they undertake human adaptations to coastal hazards as part of a wider strategy to build coastal urban resilience.

\section{CONCLUSION}

This paper set out to understand Greater Bridgetown's vulnerability to coastal hazards (SLR, storm surges and flooding) and the associated human system adaptations. It raised three key research questions to achieve its objectives: 1) In what ways is Greater Bridgetown vulnerable to coastal 
hazards? 2) What are the human dimensions of this vulnerability? and 3) What are the associated human adaptations?

We found that flooding in Barbados as a whole, and in Bridgetown specifically, is attributable to anthropogenic pressures such as built development arising from urbanization as well as rising sea-levels and storm surges resulting from climate change. A long history of colonial settlement and monocrop cultivation, namely that of sugarcane, resulted in substantial forest depletion. Bridgetown's early coastal location, urban morphology influenced by a concentration of population at the city center, and its major role as a port in the coreperiphery relationship with England through which sugarcane exports were channelled, drew investments in infrastructure and buildings along the coast. The four coastal assets referenced in this paper-Bridgetown Deepwater Harbor, Careenage, Carlisle Bay, and the UNESCO World Heritage Site-are located within the 100-year flood area and are, therefore, physically, economically, and socially vulnerable to various coastal hazards, including SLR, storm surges and flooding. Coastal inundation could lead to significant loss and/or damage in the near future. We also found that institutions in Bridgetown have traditionally been deployed to understand risks to people stemming from coastal hazards, especially flooding, and have been mandated to manage coastal development. Yet, a key finding is that the city's local institutions are weak and there is a divergence between the planning and implementation of riskfocused adaptations.

In view of our findings, we are able to derive four key empirical insights: 1) vulnerability to coastal hazards in an urban landscape is linked to the city's historical development (temporal scale), and to its urban morphology (spatial scale), 2)

\section{REFERENCES}

Aquarius Watersports Barbados (). Aquarius Watersports Barbados. Available at: https://www.aquariuswatersports.com/ (Accessed November 14, 2020).

Barbados World Heritage Committee (2011). Management Plan for Historic Bridgetown and its Garrison. (Pp. 1-1605). UNESCO World Heritage. Available at: http://www.caribbeanelections.com/eDocs/strategy/bb_strategy/ bb_Historic_Bridgetown_Management_Plan_2011.pdf (Accessed November $11,2020)$.

Becken, S., and Hay, J. E. (2008). "Climate Change Related-Risks and Adaptation," in Tourism and Climate Change: Risks and Opportunities. Editors S. Becken and J.E. Hay (Clevedon, United Kingdom: Channel View Publications).

Belle, N., and Bramwell, B. (2005). Climate Change and Small Island Tourism: Policy Maker and Industry Perspectives in Barbados. J. Travel Res. 44(1): 32-41. doi:10.1177/0047287505276589

Birkmann, J., Garschagen, M., Kraas, F., and Quang, N. (2010). Adaptive Urban Governance: New Challenges for the Second Generation of Urban Adaptation Strategies to Climate Change. Sustain. Sci. 5 (2), 185-206. doi:10.1007/s11625010-0111-3

Bulkeley, H., Edwards, G. A. S., and Fuller, S. (2014). Contesting Climate Justice in the City: Examining Politics and Practice in Urban Climate Change Experiments. Glob. Environ. Change 25, 31-40. doi:10.1016/j.gloenvcha.2014.01.009

Caribbean Development Bank (2015). Caribbean Development Bank. Available at: https://www.caribank.org/newsroom/news-and-events/cdb-approves-financingupgrade-constitution-river-barbados (Accessed October 10, 2020).

Caribbean Youth Environment Network in Barbados (). In Facebook [Organization Page]. Available at: https://www.facebook.com/CYEN246/ (Accessed November 23, 2019). that this vulnerability is further linked to its governance, particularly the institutions, laws, policies and plans that are in force, 3) that this vulnerability is significantly reduced where there are synergies between formal and informal governance, and 4) socio-political engagement is an essential component of human system adaptation in an urban landscape. Using the case of Greater Bridgetown, this paper helps demonstrate that it might not be likely for a city's capacity for coastal/urban resilience to be maximized without institutional prioritization of vulnerability, increased stakeholder "buy-in" and participation, along with significant investment in adaptation and the protection of valuable coastal infrastructure. Governance challenges in the urban space, though dynamic, can be addressed through integrating approaches to planning across temporal and spatial scales, increasing transparency, public participation and the application of conflict resolution practices, as well as robust decision-making that reflects the key tenets of good urban governance.

\section{DATA AVAILABILITY STATEMENT}

The original contributions presented in the study are included in the article/Supplementary Material, further inquiries can be directed to the corresponding author.

\section{AUTHOR CONTRIBUTIONS}

All authors listed have made a substantial, direct, and intellectual contribution to the work and approved it for publication.

Cashman, A., Cumberbatch, J., Moore, W., and Moore, W. R. (2012). The Effects of Climate Change on Tourism in Small States: Evidence from the Barbados Case. Tourism Rev. 67, 17-29. doi:10.1108/16605371211259803

Cashman, A., and Nagdee, M. R. (2017). Impacts of Climate Change on Settlements and Infrastructure in the Coastal and Marine Environments of Caribbean Small Island Developing States (SIDS). Caribbean Mar. Clim. Change Rep. Card: Sci. Rev. 2017, 155-173.

Cashman, A., Nurse, L., and John, C. (2010). Climate Change in the Caribbean: The Water Management Implications. J. Environ. Develop. 19, 42-67. doi:10.1177/ 1070496509347088

Coastal Zone Management Unit (). Carlisle Bay Marine Park. Available at: http://www. coastal.gov.bb/content/carlisle-bay-marine-park (Accessed December 11, 2020).

Coastal Zone Management Unit (). Coastal Risk Assessment and Management Programme. Available at: http://www.coastal.gov.bb/content/coastal-riskassessment-and-management-programme (Accessed December 11, 2020).

Coastal Zone Management Unit (2020a). History of the CZMU. Available at: http://www.coastal.gov.bb/content/history (Accessed December 11, 2020).

Coastal Zone Management Unit (1999). Integrated Coastal Management Plan for the West and South Coast of Barbados. Available at: http://www.coastal.gov.bb/ sites/default/files/CZMU\%20ICZM\%20Plan\%20-\%20Caribbean\%20Coast.pdf (Accessed December 11, 2020).

Coastal Zone Management Unit (2020b). Updated Draft Integrated Coastal Zone Management Plan, Vols. 1 \& 2. Available at: http://www.coastal.gov.bb/sites/ default/files/ICZM\%20Plan_Vol1.pdfhttp://www.coastal.gov.bb/sites/default/ files/ICZM\%20Plan_Vol2_Seg1.pdf (Accessed April 16, 2021).

Columbia University (2011). Comparison of the Low Elevation Coastal Zone (LECZ) Urban-Rural Estimates, Global Rural-Urban Mapping Project (GRUMP and Center for International Earth Science Information Network (CIESIN). New York, NY: National Aggregates of Geospatial Data: Population, Landscape and Climate Estimates. 
Downes, A., Cashman, A., and Lashely, J. (2015). Barbados National Report for the Third United Nations Conference on Housing and Sustainable Urban Development Habitat III. Barbados National Report for the Third United Nations Conference on Housing and Sustainable Urban Development Habitat III (Pp. 1-112). Available at: http://habitat3.org/wp-content/uploads/HabitatIII-Report-Barbados-final.pdf (Accessed December 29, 2020).

Dulal, H., Shah, K., and Nilufar, A. (2009). Social equity considerations in the implementation of Caribbean climate change adaptation policies. Sustainability 1(3): 363-383.

ECLAC (2011). "An Assessment of the Economic Impact of Climate Change on the Tourism Sector in Barbados," in Economic Commission for Latin American and the Caribbean (Accessed December 5, 2020).

ECLAC (2019). Preliminary Overview of the Economies of Latin America and the Caribbean 2019. Available at: https://repositorio.cepal.org/bitstream/handle/ 11362/45001/126/BPI2019_Barbados_en.pdf (Accessed May 6, 2021).

Forbes, D. L., James, T. S., Sutherland, M., and Nichols, S. E. (2013). Physical Basis of Coastal Adaptation on Tropical Small Islands. Sustain. Sci. 8, 327-344. doi:10.1007/s11625-013-0218-4

Gill, D., McConney, P., and Mahon, R. (2007). Socio-Economic Profile of Fisheries in the Grenadine Islands. CERMES Technical Report 11. Barbados: Centre for Resource Management and Environmental Studies (CERMES), University of the West Indies, Cave Hill Campus, 69.

Gill, D., Oxenford, H. A., and Schuhmann, P. W. (2019). "Values Associated with Reef-Related Fishing in the Caribbean - A Comparative Study," in Navigating Small-Scale Fishers Towards Viability and Sustainability: Experiences from Latin America and the Caribbean. Editors S. Salas and R. Chuenpagdees (MARE Publication Series, Springer).

Google Earth (). Google Earth. Available at: https://earth.google.com/web/ (Accessed December 11, 2020).

Government of Barbados (2018). Barbados' Second National Communication under the United Nations Framework Convention on Climate Change. Available at: https://www4.unfccc.int/sites/SubmissionsStaging/NationalReports/ Documents/4693851_Barbados-NC2-1-Barbados\%20SNC\%20FINAL\%20April\% 202018.pdf (Accessed October 15, 2020).

Government of Barbados (2008). Capacity Building in and Mainstreaming of Sustainable Land Management in Barbados (Pp. 1-51). United Nations Development Programme and the Global Environmental Facility. Available at: https://info.undp.org/docs/pdc/Documents/BRB/00040957_46566\% 20PRODOC.pdf (Accessed December 11, 2020).

Government of Barbados (2011). Historic Bridgetown and its Garrison Management Plan. (1-96), http://www.caribbeanelections.com (Accessed April 30, 2021).

Government of Barbados (2017). Physical Development Plan 2017. Available at: http://www.townplanning.gov.bb/pdp/ (Accessed November 11, 2020).

Hatfield-Dodds, S., Nelson, R., and Cook, D. (2007). "Adaptive Governance: An Introduction, and Implications for Public Policy," in Paper Presented at the 51st Annual Conference of the Australian Agricultural and Resource Economics Society, Queenstown, New Zealand, February 13-16, 2007 (Noosa, Australia: ANZSEE). Available at: https://core.ac.uk/download/pdf/6418177.pdf (Accessed April 15, 2021).

Hay, J., Duvat, V., and Magnan, A. K. (2019). "Trends in Vulnerability to ClimateRelated Hazards in the Pacific: Research, Understanding and Implications," in The Oxford Handbook of Planning for Climate Change Hazards. Editors W. T. Pfeffer, J. B. Smith, and K. L. Ebi (London, United Kingdom: Oxford University Press).

Hinkson, D. (2019). "Port Plays a Big Role," Barbados Today. Available at: https:// barbadostoday.bb/2019/10/16/port-plays-significant-role/ (Accessed November 20, 2020).

Hsieh, H.-F., and Shannon, S. E. (2005). Three Approaches to Qualitative Content Analysis. Qual. Health Res. 15 (9), 1277-1288. doi:10.1177/1049732305276687

Inniss, T. (2012). "Heritage and Communities in a Small Island Developing State: Historic Bridgetown and its Garrison, Barbados," in World Heritage: Benefits Beyond Borders. Editor A. Galla (Cambridge, United Kingdom: Cambridge University Press), 69-81.

Inter-American Development Bank (). Emerging and Sustainable Cities Programme. Available at: https://www.iadb.org/en/urban-development-and-housing/ emerging-and-sustainable-cities-program (Accessed December 11, 2020).

IPCC (2014). "Annex II: Glossary," in Climate Change 2014: Impacts, Adaptation, and Vulnerability. Part B: Regional Aspects. Contribution of Working Group II to the Fifth Assessment Report of the Intergovernmental Panel on Climate Change. Editor V. R. Barros, et al. (Cambridge, United Kingdom: Cambridge University Press), 1757-1776.

Jaja, J., Dawson, J., and Gaudet, J. (2017). Using Social Network Analysis to Examine the Role that Institutional Integration Plays in Community-Based Adaptive Capacity to Climate Change in Caribbean Small Island Communities. Local Environ. 22, 424-442. doi:10.1080/13549839.2016.1213711

Joy, S. (2018). Next Town Planning Consultation July 25. Available at: https:// gisbarbados.gov.bb/blog/reforming-town-planning/ (Accessed November 7, 2019).

Leslie, J. (2010). Socio-economic Monitoring in Oistins, Barbados. CERMES Technical Report No. 29. Cave Hill: Centre for Resource Management and Environmental Studies. Available at: https://repository.library.noaa.gov/view/ noaa/819 (Accessed April 15, 2021).

Lorde, T., Francis, B., and Drakes, L. (2011). Tourism Services Exports and Economic Growth in Barbados. Int. Trade J. 25 (2), 205-232. doi:10.1080/ 08853908.2011.554788

McConney, P., Nicholls, V., and Simmons, B. (2012). "Women in a Fish Market in Barbados," in Proceedings of the 65th Gulf and Caribbean Fisheries Institute, Santa Marta, Colombia, November 5-9, 2012. Available at: http:// aquaticcommons.org/21432/1/GCFI_65-5.pdf (Accessed April 15, 2021).

McHardy, P., and Donovan, M. G. (2016). The State of Social Housing in Six Caribbean Countries. Wasington, DC: Inter-American Development Bank (IDB). Available at: https://publications.iadb.org/publications/english/document/ The-State-of-Social-Housing-in-Six-Caribbean-Countries.pdf (Accessed December $28,2020)$.

Medina, R., McCue, J., Merino, M., Aragon, G., Barker, H., Aguirre, I., et al. (2019). "Development of a Draft Updated Integrated Coastal Management Plan and Amendment of the Coastal Zone Management Act and Preparation of CZM Regulations Incorporating Disaster Risk Management and Climate Change Adaptation Principles," Draft Policy Paper (Deliverable 6), http://www.coastal. gov.bb/sites/default/files/Del\%206\%20-\%20Draft\%20Policy\%20Paper\%2011\% 20October\%20for\%20consultation.pdf (Accessed April 30, 2021).

Monioudi, I. N., Asariotis, R., Becker, A., Bhat, C., Dowding-Gooden, D., Esteban, M., et al. (2018). Climate Change Impacts on Critical International Transportation Assets of Caribbean Small Island Developing States (SIDS): The Case of Jamaica and Saint Lucia. Reg. Environ. Change 18 (8), 2211-2225. doi:10.1007/s10113-018-1360-4

Monnereau, I., and Oxenford, H. A. (2017). Impacts of Climate Change on Fisheries in the Coastal and Marine Environments of Caribbean Small Island Developing States (SIDS). Caribbean Mar. Clim. Change Rep. Card: Sci. Rev. 2017, 124-154.

MPAtlas (). Carlisle Bay. Available at: http://www.mpatlas.org/mpa/sites/ 67706802/ (Accessed November 20, 2019).

Mumby, P., Flower, J., Chollett, I., Box, S., Bozec, Y-M., Fitzsimmons, C., et al. (2014). Towards Reef Resilience and Sustainable Livelihoods: A Handbook for Caribbean Coral Reef Managers. Exeter, United Kingdom: University of Exeter.

Mycoo, M. A. (2017). A Caribbean New Urban Agenda Post-habitat III: Closing the Gaps. Habitat Int. 69, 68-77. doi:10.1016/j.habitatint.2017.09.001

Mycoo, M. A. (2018). Beyond $1.5^{\circ} \mathrm{C}$ : Vulnerabilities and Adaptation Strategies for Caribbean Small Island Developing States. Reg. Environ. Change 18, 2341-2353. doi:10.1007/s10113-017-1248-8

Mycoo, M., and Chadwick, A. (2012). Adaptation to Climate Change: The Coastal Zone of Barbados. Proc. Inst. Civil Eng. - Maritime Eng. 165 (4), 159-168. doi:10.1680/maen.2011.19

Mycoo, M., and Donovan, M. G. (2017). A Blue Urban Agenda: Adapting to Climate Change in the Coastal Cities of the Caribbean and Pacific Small Island Developing States. Washington, DC: Inter-American Development Bank. Available at: https:// publications.iadb.org/en/blue-urban-agenda-adapting-climate-change-coastalcities-caribbean-and-pacific-small-island (Accessed December 11, 2020).

Mycoo, M. (2006). Sustainable Tourism Using Regulations, Market Mechanisms and Green Certification: A Case Study of Barbados. J. Sustain. Tourism 14 (5), 489-511. doi:10.2167/jost600.0

Mycoo, M. (2014). Sustainable Tourism, Climate Change and Sea Level Rise Adaptation Policies in Barbados. Nat. Resour. Forum 38, 47-57. doi:10.1111/ 1477-8947.12033

Nguyen, C., and Robinson, S. (2019). Differential Climate Change Impacts and Adaptation Responses in the Caribbean Lesser Antilles. Caribbean Geogr. $24,1-23$. 
Nunn, P., and Kumar, R. (2018). Understanding Climate-Human Interactions in Small Island Developing States (SIDS). Int. J. Clim. Change Strateg. Manage. 10, 245-271. doi:10.1108/ijccsm-01-2017-0012

Nurse, L. A. (2015). "Assessing the Vulnerability of Air and Seaports in Small Islands: Risk Factors and Adaptation Guidelines," in International Scientific Conference: Our Common Future under Climate Change, 7-10 July 2015 (Accessed December 21, 2020).

Nurse, L. A. (2011). Climate Change Impacts and Adaptation: A Challenge for Global Ports. Bridgetown: University of the West Indies, Cave Hill Campus.

Nurse, L. A. (2017). "Climate Change Projections for the Caribbean and Implications for Air and Sea Ports," in UNCTAD National Workshop" Climate Change Impacts \& Adaptation for Coastal Transport Infrastructure in Caribbean SIDS," Castries, St. Lucia, May 24-26, 2017.

Nurse, L. A., McLean, R. F., Agard, J., Briguglio, L. P., Duvat-Magnan, V., Pelesikoti, N., et al. (2014). "Small Islands," in Climate Change 2014: Impacts, Adaptation, and Vulnerability. Part B: Regional Aspects. Contribution of Working Group II to the Fifth Assessment Report of the Intergovernmental Panel on Climate Change. Editors V. R. Barros, C. B. Field, D. J. Dokken, M. D. Mastrandrea, K. J. Mach, T. E. Bilir, et al. (Cambridge, United Kingdom: Cambridge University Press), 1613-1654.

Oppenheimer, M., Glavovic, B. C., Hinkel, J., van de Wal, R., Magnan, A. K., and Abd-Elgawad, A., et al. (2019). "Sea Level Rise and Implications for Low-Lying Islands, Coasts and Communities," in IPCC Special Report on the Ocean and Cryosphere in a Changing Climate, In press. Editors H.-O. Pörtner, D. C. Roberts, V. Masson-Delmotte, P. Zhai, M. Tignor, E. Poloczanska, et al. Available at: https:/www.ipcc.ch/site/assets/uploads/sites/3/2019/11/ 08_SROCC_Ch04_FINAL.pdf (Accessed April 16, 2021).

Patterson, J. J., and Huitema, D. (2019). Institutional Innovation in Urban Governance: The Case of Climate Change Adaptation. J. Environ. Plann. Manage. 62 (3), 374-398. doi:10.1080/09640568.2018.1510767

Pelling, M. (2003). The Vulnerability of Cities: Natural Disasters and Social Resilience. London, United Kingdom: Earthscan Publications Ltd.

Potter, R. B. (2000). Urban Housing in Barbados, West Indies. Geographical J. 155 (1), 81-93. doi:10.2307/635384

Pugh, J. (2006). "Physical Development Planning in the Anglophone Caribbean: The Re-Articulation of Formal State Power," in Environmental Planning in the Caribbean. Editors J. Pugh and J. H. Momsen (Hampshire, United Kingdom: Ashgate Publishing Limited), 7-20.

Pugh, J. (2013). Speaking Without Voice: Participatory Planning, Acknowledgment, and Latent Subjectivity in Barbados. Ann. Assoc. Am. Geogr. 103 (5), 1266-1281. doi:10.1080/00045608.2012.706571

Richardson-Ngwenya, P., and Momsen, J. (2017). "Tourism and Agriculture in Barbados: Changing Relationships," in Tourism and Agriculture: New Geographies of Consumption, Production and Rural Restructuring. Editors R. M. Torres and J. H. Momsen (London and New York: Routledge).

Robinson, S.-a. (2020b). A Richness Index for Baselining Climate Change Adaptations in Small Island Developing States. Environ. Sustain. Indic. 8, 100065. doi:10.1016/j.indic.2020.100065

Robinson, S.-a. (2018). Climate Change Adaptation in Small Island Developing States: Insights and Lessons from a Meta-Paradigmatic Study. Environ. Sci. Pol. 85, 172-181. doi:10.1016/j.envsci.2018.03.030

Robinson, S.-a. (2017). Climate Change Adaptation Trends in Small Island Developing States. Mitig Adapt Strateg. Glob. Change 22 (4), 669-691. doi:10.1007/s11027-015-9693-5
Robinson, S. a. (2020a). Climate Change Adaptation in SIDS : A Systematic Review of the Literature Pre and Post the IPCC Fifth Assessment Report. Wires Clim. Change 11 (4), 1-21. doi:10.1002/wcc.653

Schueler, K. (2016). Nature-Based Solutions to Enhance Coastal Resilience. Washington, DC: Inter-American Development Bank. Available at: https://publications.iadb.org/publications/english/document/Naturebased-Solutions-to-Enhance-Coastal-Resilience.pdf (Accessed April 13, 2021).

Scott, D., Simpson, M. C., and Sim, R. (2012). The Vulnerability of Caribbean Coastal Tourism to Scenarios of Climate Change Related Sea Level Rise. J. Sustain. Tourism 20 (6), 883-898. doi:10.1080/ 09669582.2012 .699063

Seijas, A. (2015). "Bridgetown 360: 5 Ideas to Revitalize the City". Ciudades Sostnibles: Urban Development. Available at: https://blogs.iadb.org/ciudadessostenibles/en/bridgetown/ (Accessed December 29, 2020).

SGP The GEF Small Grants Programme (). The Conservation of the Marne Environment along the South Coast of Barbados (Phase 1). Available at: https://sgp.undp.org/ sgpundp/index.php?option=com_sgpprojects\&view= projectdetail\&id=8298\&Itemid=272 (Accessed December 29, 2020).

Smith, F. H., and Watson, K. (2008). Urbanity, Sociability, and Commercial Exchange in the Barbados Sugar Trade: A Comparative Colonial Archaeological Perspective on Bridgetown, Barbados in the Seventeenth Century. Int. J. Histor Archaeol 13, 63-79. doi:10.1007/ s10761-008-0072-8

Thompson, R. (2013). Stronger Shoreline. Nation News. Available at: https://www. nationnews.com/nationnews/news/32148/stronger-shoreline (Accessed December 11, 2020).

Town and Country Development Planning Office (2017a). Barbados Physical Development Plan 2017. Available at: http://www.townplanning.gov.bb/pdp/ (Accessed December 29, 2020).

Town and Country Development Planning Office (2017d). History of the PDP. Available at: http://www.townplanning.gov.bb/pdp/history/ (Accessed December 29, 2020).

Town and Country Development Planning Office (2017c). Strategic Policies. Available at: http://www.townplanning.gov.bb/pdp/Downloads/files/pdp/A02_Strategic\%20Policies.pdf (Accessed December 29, 2020).

Town and Country Development Planning Office (2017b). "Bridgetown Community Plan. Bridgetown Community Plan", (Pp. 1-70). Bridgetown. Available at: http://www.townplanning.gov.bb/pdp/Downloads/files/pdp/B07_Bridgetown.pdf (Accessed December 29, 2020).

Welch, P. L. V. (2004). Slave Society in the City: Bridgetown, Barbados 1680-1834. Kingston: Ian Randle Publishers.

Conflict of Interest: The authors declare that the research was conducted in the absence of any commercial or financial relationships that could be construed as a potential conflict of interest.

Copyright (C) 2021 Mycoo, Robinson, Nguyen, Nisbet and Tonkel. This is an openaccess article distributed under the terms of the Creative Commons Attribution License (CC BY). The use, distribution or reproduction in other forums is permitted, provided the original author(s) and the copyright owner(s) are credited and that the original publication in this journal is cited, in accordance with accepted academic practice. No use, distribution or reproduction is permitted which does not comply with these terms. 